\begin{tabular}{|l|l|l||}
\hline \multicolumn{2}{|c|}{ PublisherInfo } \\
\hline \hline PublisherName & $:$ & BioMed Central \\
\hline \hline PublisherLocation & $:$ & London \\
\hline \hline PublisherImprintName & $:$ & BioMed Central \\
\hline \hline
\end{tabular}

\title{
Painting the fourth
}

\begin{tabular}{|l|l|l||}
\hline \multicolumn{2}{|c|}{ ArticleInfo } \\
\hline \hline ArticleID & $:$ & 4092 \\
\hline \hline ArticleDOI & $:$ & $10.1186 /$ gb-spotlight-20010522-02 \\
\hline \hline ArticleCitationID & $:$ & spotlight-20010522-02 \\
\hline \hline ArticleSequenceNumber & $:$ & 163 \\
\hline \hline ArticleCategory & $:$ & Research news \\
\hline \hline ArticleFirstPage & $:$ & 1 \\
\hline \hline ArticleLastPage & $:$ & 2 \\
\hline \hline & & RegistrationDate : 2001-05-22 \\
ArticleHistory & $:$ & OnlineDate $\quad$ 2001-05-22 \\
\hline \hline ArticleCopyright & $:$ & BioMed Central Ltd2001 \\
\hline \hline ArticleGrants & $:$ & \\
\hline \hline ArticleContext & $:$ & 130592211 \\
\hline \hline
\end{tabular}




\section{Jonathan B Weitzman}

Email: jonathanweitzman@hotmail.com

Chromosome 4 of Drosophila melanogaster is an atypical autosome, exhibiting several features characteristic of the X chromosome. In the May 22 Proceedings of the National Academy of Sciences, Larsson et al. report the molecular cloning of Painting of fourth (Pof), which encodes a protein that specifically paints chromosome 4 (Proc Natl Acad Sci USA 2001, 98:6273-6278). The POF protein sequence contains a putative RNA-binding domain. POF protein decorates chromosome 4 by spreading out from an initiation site in the proximal region of the chromosome. In the related fruitfly species Drosophila busckii, POF paints the whole X chromosome, exclusively in males. This study supports the idea that there are similarities between the chromosome 4 autosome and the X chromosome. POF complexes may function like the Male Lethal Specific proteins, which regulate dosage-compensation of the $\mathrm{X}$ chromosome.

\section{References}

1. The Drosophila chromosome 4 site, [http://www.biology.ualberta.ca/dros4.hp/4th_main.htm]

2. Proceedings of the National Academy of Sciences, [http://www.pnas.org]

This PDF file was created after publication. 